\title{
Maternal and genetic influences on egg size and larval performance in a seed beetle (Callosobruchus maculatus): multigenerational transmission of a maternal effect?
}

\author{
CHARLES W. FOX \\ Department of Entomology, University of California, Davis, CA 95616, U.S.A.
}

\begin{abstract}
The mechanisms by which maternal effects are transmitted across generations are variable among characters and taxa. Because egg size is simultaneously a maternal and offspring character, and variation in egg size often has implications for offspring life histories, egg size may facilitate multigenerational transmission of maternal effects. The relative contributions of genetic and maternal effects to variation in egg size and offspring performance (body size and development time), with an emphasis on maternal contributions to offspring egg sizes (and thus granddaughter phenotype), are estimated in the seed beetle, Callosobruchus maculatus, using a half-sib quantitative genetic design. Both body size and egg size (egg length and width) were highly heritable characters (estimated $h^{2}>0.55$ for each character), and the proportion of the variance explained by maternal effects was near zero for each. Maternal effects do, however, appear to affect early larval life history, through a female body size effect on hatchling resources (estimated as egg size). This initial disadvantage to larvae results in extended larval development time, but not in an effect on final adult size. These results indicate that variation in egg size and body size are not maternally transmitted across generations, but instead that most of the variation in body size and egg size is additive genetic variation.
\end{abstract}

Keywords: Callosobruchus maculatus, egg size, genetic correlations, heritability, life history, maternal effects.

\section{Introduction}

Maternal effects have recently become recognized as important in the evolution of natural populations (Riska, 1990; Mousseau \& Dingle, 1991). They may result in large time lags in an evolutionary response to selection, and characters subject to large maternal effects may even respond to selection in a maladaptive direction (Riska et al., 1985; Kirkpatrick \& Lande, 1989; Lande \& Kirkpatrick, 1990). They also confound our interpretation of within- and amongpopulation variation in morphological and life history traits (Sinervo, 1990).

The mechanisms by which maternal effects are transmitted across generations are variable among characters and taxa (Mousseau \& Dingle, 1991). Propagule size may be a particularly important life history character involved in maternal effects transmission because it is simultaneously a maternal and offspr- ing character (Sinervo, 1990); eggs are produced by mothers, but also determine initial offspring resources/ size. Large maternal influences on seed phenotype have been detected in higher plants (e.g. Antonovics \& Schmidt, 1986; Roach \& Wulff, 1987; Lacey, 1990; Schwaegerle \& Levin, 1990; Biere, 1991; Platenkamp $\&$ Shaw, 1993), and these seed characters are observed to affect progeny fitness (e.g. Stanton, 1984; Wulff, 1986a,b; Mazer, 1987; Douglas et al., 1993; Huyghe, 1993; Thompson et al., 1993; Zhang \& Maun, 1993; reviewed in McGinley et al., 1987). Similarly, maternal size generally affects egg size in animals (e.g. Harvey, 1983; Berger, 1989; Larsson \& Forslund, 1992) and this egg size variation often has large effects on offspring fitness in both insects (Richards \& Myers, 1980; Steinwascher, 1984; Yuma, 1984; Honek, 1987; Sibly \& Monk, 1987; Simmons, 1988; Solbreck et al., 1989; Carlberg, 1991; Rossiter, 1991; Tauber et al., 1991; Sota \& Mogi, 1992; Wallin et al., 1992) and verte- 
brates (Kaplan, 1980a,b; Reid \& Boersma, 1990; Marteinsdottir \& Abele, 1992; reviewed in Fleming \& Gross, 1990; Kaplan, 1990; Reznick, 1990). Thus, maternal size can affect propagule size, which in turn can affect offspring performance (including offspring size), which subsequently affects propogule size again. As a result, maternal variation in body size and egg size can be transmitted across multiple generations (Falconer, 1965).

Large amounts of variation in egg size are present within populations of the seed beetle, Callosobruchus maculatus (Coleoptera: Bruchidae) (Fox, 1993, 1994). This variation results from both phenotypic variation among females, in which larger females lay larger eggs (Fox, 1993), as well as within-female variation due to maternal age effects (older females lay smaller eggs: Wasserman \& Asami, 1985; Fox, 1993). In addition, observed egg size variation has serious implications for offspring life histories: offspring from larger eggs develop faster and are larger than offspring from small eggs (Fox, 1994). This effect of egg size on offspring life histories is particularly important for C. maculatus because multiple females frequently lay eggs on a single seed (Mitchell, 1975; Messina \& Renwick, 1985a, b; Wilson, 1988) and thus multiple larvae compete for a limited resource (Messina, 1991; Toquenaga, 1993). These observations have led me to speculate that egg size is under balancing selection, with large eggs favoured when multiple eggs are laid on a host (Fox, 1994), while small eggs are favoured when one or few eggs are laid on a host (due to an egg size-egg number trade-off; Berrigan, 1991). However, it is unknown to what extent egg size variation is genetic, and to what extent the observed variation in egg size, and subsequent offspring performance, is due to maternal effects.

Here, I investigate the relative contributions of genetic and maternal effects to variation in egg size and offspring performance (body size and development time), with an emphasis on maternal contributions to offspring egg sizes (and thus granddaughter phenotype).

\section{Materials and methods}

Callosobruchus maculatus is a cosmopolitan pest of stored legumes (Fabaceae), particularly beans of the genus Vigna. Females cement their eggs to the surface of host seeds (Messina, 1991). Approximately 4-5 days later (at $26-28^{\circ} \mathrm{C}$ ), the eggs hatch and the first instar larvae burrow through the seed coat and into the seed. Larval development and pupation are completed entirely within a single seed. This beetle's short generation time and ease of laboratory rearing in seminatural storage environments make $C$. maculatus an excellent animal for life history studies. All beetles used in these experiments were collected from infested pods of cowpea (Vigna unguiculata) in Niamey, Niger, at the University of Niamey Experiment Station, and maintained in laboratory growth chambers for 37 generations, at $>1500$ adults per generation, prior to this experiment.

A traditional half-sib design was used to estimate both genetic and maternal effects on egg size and offspring performance (Falconer, 1989); 50 sires were each mated to four different dams, creating 198 families (two females did not produce eggs). Virgin females collected within $12 \mathrm{~h}$ of emergence from isolated host seeds were presented with a male in a $35 \mathrm{~mm}$ petri dish and allowed to copulate. Following a single copulation, each female was transferred to a 60 $\mathrm{mm}$ petri dish containing approximately 20 dry cowpea seeds ( $V$. unguiculata) and allowed to oviposit for $12 \mathrm{~h}$. These females were subsequently transferred to a second $60 \mathrm{~mm}$ petri dish with 20 seeds and allowed to lay eggs for another $12 \mathrm{~h}$.

All eggs were reared to adult at densities of one beetle per seed (excess eggs were scraped off), at $26^{\circ} \mathrm{C}$, and under constant light. Emerging adults were collected and weighed individually within $12 \mathrm{~h}$ of adult emergence. Development time was estimated as the time between egg-laying and adult emergence, and thus includes embryonic, larval and pupal development time. Length and width of all parental eggs laid during the first $12 \mathrm{~h}$ postmating were measured using an optical micrometer on a $50 \times$ dissecting microscope. In addition, eggs of all female offspring were collected by mating females within $1 \mathrm{~h}$ of weighing them, and then transferring them to $35 \mathrm{~mm}$ petri dishes containing approximately 25 seeds of azuki, Vigna angularis. Azuki seed (which is red) was used here instead of cowpea (which is white) because eggs are more easily measured against a red background. Females from this population readily accept azuki as an alternative host to cowpea (Chiu \& Messina, 1994), and host effects on egg size were not detected in preliminary analyses. Females were allowed to lay eggs for $12 \mathrm{~h}$, and were then dispatched. Eggs were stored at room temperature until it was convenient to measure them. Because eggs contain only dry frass (excrement) after larvae burrow into a seed, long-term storage does not distort egg characters (C. Fox, unpublished data). Three randomly selected eggs from each female were later measured as described above.

\section{Results}

In total, 3184 offspring ( 1522 females and 1662 males) were reared from 198 full-sib families (50 sires and 


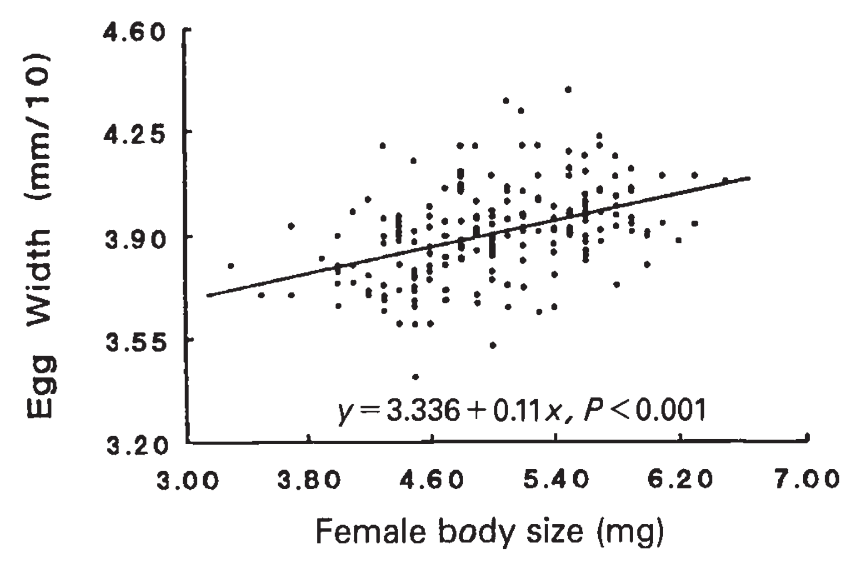

Fig. 1 The relationship between female weight and the width of her eggs for Callosobruchus maculatus. The relationship between female weight and egg length is similar $(y=5.93+0.09 x, P<0.001)$. Data are for the parents used to initiate the half-sib families. The relationship between female size and egg size of female offspring (daughters of these females) is presented in Table 5.
198 dams). Of these, body weight data were collected for 3163 offspring, and egg size data (both length and width) were collected for 1271 female offspring. Overall egg-to-adult survivorship in this experiment was $97.3 \pm 0.5$ per cent, such that biases due to inadvertent selection during the experiment should be negligible.

\section{Female size affects the size of her eggs}

Size of parental females was positively correlated with both the length and width of their eggs (Fig. 1). There was no effect of male size on the size of eggs his mate produced (egg length vs. paternal weight, $R^{2}<0.001$, $P>0.05$; egg width vs. paternal weight, $R^{2}<0.001$, $P>0.05)$.

\section{Genetic and maternal effects on life history characters}

In an analysis of variance, large sire and dam (nested within sire) effects were detected for offspring adult

Table 1 Nested analyses of variance for offspring development time and body size in Callosobruchus maculatus

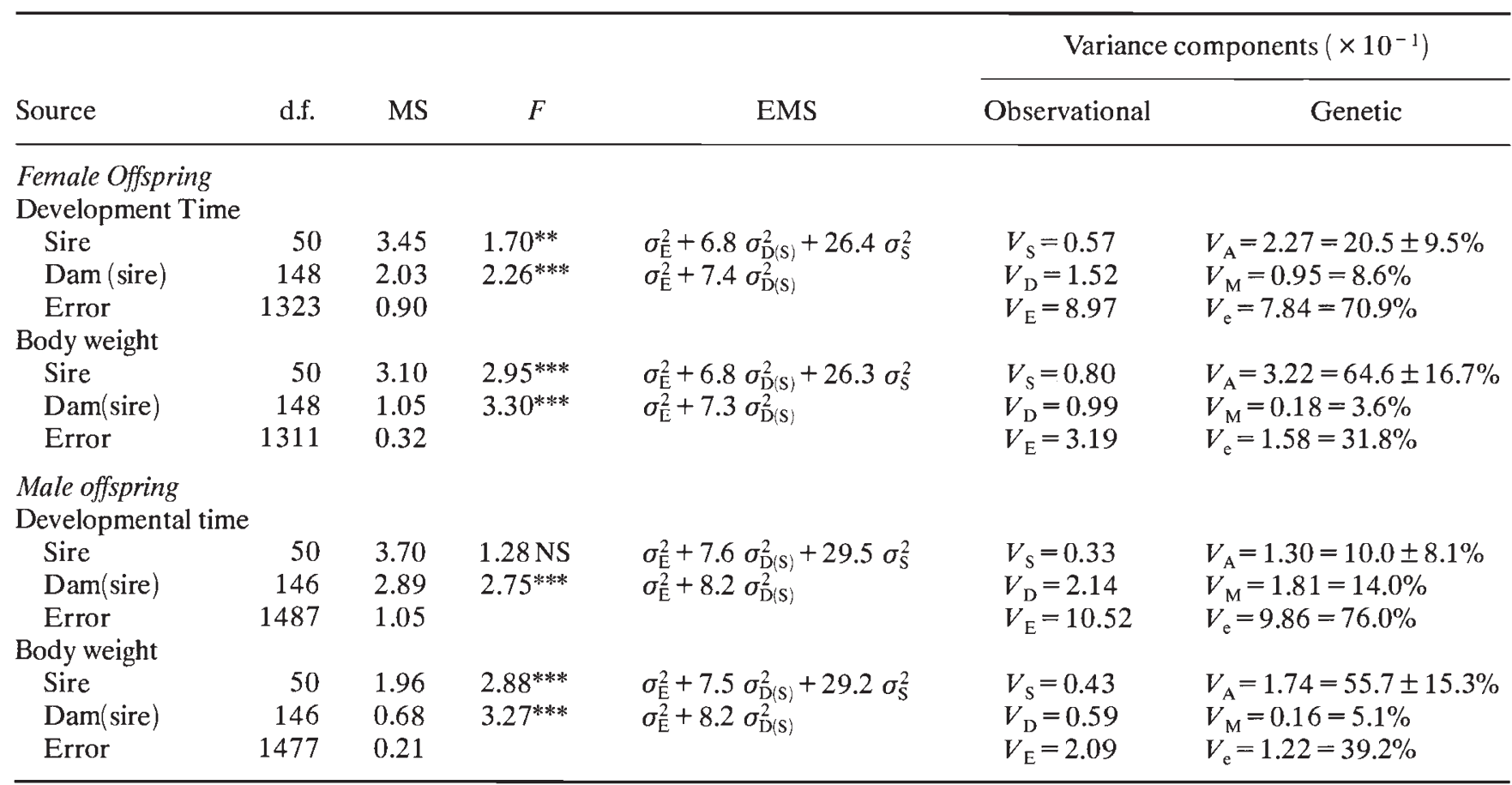

Type III sums of squares were calculated using SAS GLM (SAS Institute, 1985). Expected mean squares were obtained using the random option of SAS GLM. Variance components were estimated using the restricted maximum likelihood method of SAS VARCOMP.

The maternal effects variance $\left(V_{\mathrm{M}}\right)$ is calculated assuming that the dominance variance and higher order interactions (e.g. $V_{\mathrm{AA}}$, $\left.V_{\mathrm{AAA}}\right)=0$.

Standard errors for the percentage $V_{\mathrm{P}}$ explained by $V_{\mathrm{A}}$ are calculated following Becker (1992).

${ }^{* *} P<0.01,{ }^{* *} P<0.001$; NS, not significant; $V_{\mathrm{S}}$, among sire variance; $V_{\mathrm{D}}$, among dam variance; $V_{\mathrm{E}}$, error variance in ANOVA; $V_{\mathrm{A}}$, additive genetic variance; $V_{\mathrm{M}}$, maternal variance; $V_{\mathrm{e}}$, environmental variance. 
Table 2 Nested analyses of variance for offspring egg size in Callosobruchus maculatus

\begin{tabular}{|c|c|c|c|c|c|c|}
\hline \multirow[b]{2}{*}{ Source } & \multirow[b]{2}{*}{ d.f. } & \multirow[b]{2}{*}{ MS } & \multirow[b]{2}{*}{$F$} & \multirow[b]{2}{*}{ EMS } & \multicolumn{2}{|c|}{ Variance components $\left(\times 10^{-2}\right)$} \\
\hline & & & & & Observational & Genetic \\
\hline \multicolumn{7}{|l|}{ Egg length } \\
\hline Sire & 50 & 0.28 & $3.38 * * *$ & $\sigma_{\mathrm{E}}^{2}+5.7 \sigma_{\mathrm{D}(\mathrm{S})}^{2}+21.7 \sigma_{\mathrm{S}}^{2}$ & $V_{\mathrm{S}}=1.07$ & $V_{\mathrm{A}}=4.28=73.8 \pm 17.4 \%$ \\
\hline $\operatorname{Dam}($ sire $)$ & 143 & 0.08 & $2.09 * * *$ & $\sigma_{\mathrm{E}}^{2}+6.3 \sigma_{\mathrm{D}(\mathrm{S})}^{2}$ & $V_{\mathrm{D}}=0.73$ & $V_{\mathrm{M}}=0=0.0 \% \dagger$ \\
\hline Sire & 50 & 0.10 & $2.78^{* * * * * *}$ & $\sigma_{\mathrm{E}}^{2}+5.7 \sigma_{\mathrm{D}(\mathrm{S})}^{2}+21.7 \sigma_{\mathrm{S}}^{2}$ & $V_{\mathrm{S}}=0.31$ & $V_{\mathrm{A}}=1.26=59.8 \pm 16.5 \%$ \\
\hline $\operatorname{Dam}($ sire $)$ & 143 & 0.04 & $2.67 * * *$ & $\sigma_{\mathrm{E}}^{2}+6.3 \sigma_{\mathrm{D}(\mathrm{S})}^{2}$ & $V_{\mathrm{D}}=0.38$ & $V_{\mathrm{M}}=0.06=2.9 \%$ \\
\hline Error & 1077 & 0.01 & & & $V_{\mathrm{E}}=1.41$ & $V_{\mathrm{e}}=0.78=37.3 \%$ \\
\hline
\end{tabular}

Type III sums of squares were calculated using SAS GLM (SAS Institute, 1985). Expected mean squares were obtained using the random option of SAS GLM. Variance components were estimated using the restricted maximum likelihood method of SAS VARCOMP.

The maternal effects variance $\left(V_{\mathrm{M}}\right)$ is calculated assuming that the dominance variance and higher order interactions (e.g. $V_{\mathrm{AA}}$, $\left.V_{\text {AAA }}\right)=0$.

Standard errors for the percentage $V_{\mathrm{P}}$ explained by $V_{\mathrm{A}}$ are calculated following Becker (1992).

*** $P<0.001 ; V_{\mathrm{S}}$, among sire variance; $V_{\mathrm{D}}$, among dam variance; $V_{\mathrm{E}}$, error variance in ANOvA; $V_{\mathrm{A}}$, additive genetic variance; $V_{\mathrm{M}}$, maternal variance; $V_{\mathrm{e}}$, environmental variance.

†Estimate of $V_{M}$ was negative and thus equated to 0 .

body weight (Table 1), egg length, and egg width (Table 2). These translated into large estimates of additive genetic variance $\left(V_{\mathrm{A}}\right)$, and high heritabilities, ranging from $0.56 \pm 0.15$ for male body weight to $0.74 \pm 0.17$ for egg length (Table 3 ). The largest proportion of variance due to maternal effects for these characters was 5.1 per cent (Tables 1 and 2), substantially smaller than the proportion due to additive effects. Although standard errors are not available for estimates of maternal effects, it is clear that they are very small and not likely to be statistically different from zero.

When rearing-dish effects, nested within the sire $\times$ dam interaction, were introduced into the models presented in Tables 1 and 2, they were not significant for any character. In addition, rearing dish explained an average of only 3.4 per cent of the variance for each character (estimated using SAS VARCOMP, restricted maximum likelihood method; SAS Institute, 1985). Thus, rearing dish was deleted from all subsequent analyses, and is not presented here.

Heritability estimates based on parent-offspring regressions for body weight and egg size (in which male offspring were regressed against sire, and female offspring against dam; $h^{2}=$ twice the slope) are consistent with the estimates from the half-sib analyses in indicating high heritabilities (Table 3). These parent-offspring estimates also indicate that maternal effects do not contribute to body size variation. Half of the maternal effects variance is contained in the mother-daughter estimate of $h^{2}$, while none of the
Table 3 The heritability of life history characters of Callosobruchus maculatus calculated from the sire variance component in an analysis of variance and the regression of mean offspring phenotype on maternal phenotype

\begin{tabular}{lcc}
\hline Character & Half-sib estimate & Regression* \\
\hline Females & & \\
$\quad$ Egg length & $0.74 \pm 0.17$ & $0.59 \pm 0.10$ \\
$\quad$ Egg width & $0.60 \pm 0.17$ & $0.43 \pm 0.08$ \\
$\quad$ Body length & $0.65 \pm 0.17$ & $0.57 \pm 0.11$ \\
$\quad$ Development time & $0.21 \pm 0.10$ & - \\
Males & & \\
$\quad$ Body weight & $0.56 \pm 0.15$ & $0.53 \pm 0.07$ \\
$\quad$ Development time & $0.10 \pm 0.08$ & - \\
\hline
\end{tabular}

*Since C. maculatus is sexually dimorphic, female offspring are regressed against their mothers and male offspring are regressed against their fathers.

Standard errors on the half-sib estimates are calculated following the procedure of Becker (1992).

Parent-offspring heritability estimates are not available for development time because these data were not collected for parents.

maternal effects variance is contained in the father-son estimate (Becker, 1992). Thus, we expect the heritability estimate for female size to be larger than the estimate for male size if the maternal effects variance was nonzero (due to substantial sexual dimorphism, we cannot compare daughters regressed against their 
fathers, or sons regressed against their mothers). However, these two parent-offspring estimates are similar, indicating a near-zero maternal effect on body size.

In contrast to the results for egg size and body size, the sire effect on development time, and thus the heritability of development time, was significantly different from zero only for female offspring (Table 1 , $\left.h^{2}=0.21 \pm 0.09\right)$. The estimated proportion of the variance due to maternal effects ranged from $8.6 \mathrm{per}$ cent for females to 14.0 per cent for males. This estimate of 14.0 per cent for males is larger than the estimated contribution of additive genetic effects, and suggests a large contribution of maternal effects to the variance of development time in $C$. maculatus (relative to the genetic effects). Development time data were not collected on parents, and thus parent-offspring regressions could not be compared to the half-sib analyses.

\section{Maternal age effects}

During the set-up of this experiment, eggs were collected from parent females in two $12 \mathrm{~h}$ batches over a $24 \mathrm{~h}$ period. Thus, a maternal age effect within the first $24 \mathrm{~h}$ can be examined by including age as a fixed effect with two levels in the analyses of variance. Age had no detectable effect on any character except development time (Table 4). For development time, the effects of both maternal age and the age $\times$ dam inter-

Table 4 Analyses of variance examining the effect of maternal age on offspring development time, body size and egg size in Callosobruchus maculatus

\begin{tabular}{|c|c|c|c|c|c|}
\hline Source & d.f. & MS & $F$ & $\begin{array}{r}\text { Pro } \\
\text { va }\end{array}$ & $\begin{array}{l}\text { rtion } \\
\text { ance }\end{array}$ \\
\hline \multicolumn{6}{|l|}{ Development time } \\
\hline Sex & 1 & 21.09 & $23.89^{* * * *}$ & Males & Females \\
\hline Sire & 50 & 5.20 & $1.40 \mathrm{NS}$ & $2.6 \%$ & $4.7 \%$ \\
\hline $\operatorname{Dam}($ sire $)$ & 148 & 3.71 & $4.04^{* * *}$ & $13.1 \%$ & $8.2 \%$ \\
\hline Maternal age & 1 & 12.07 & $13.17^{* * *}$ & $1.6 \%$ & $0.7 \%$ \\
\hline Age $\times$ dam $($ sire $)$ & 192 & 1.76 & $1.92^{* * * *}$ & $5.2 \%$ & $12.1 \%$ \\
\hline Age $\times$ sex & 1 & 1.10 & $1.20 \mathrm{NS}$ & - & - \\
\hline Error & 2812 & 0.92 & & $77.4 \%$ & $74.4 \%$ \\
\hline \multicolumn{6}{|l|}{ Body weight } \\
\hline Sex & 1 & 1013.35 & $3762.80^{* * *}$ & Males & Females \\
\hline Sire & 50 & 4.31 & $3.17^{* * *}$ & $14.0 \%$ & $16.1 \%$ \\
\hline $\operatorname{Dam}($ sire $)$ & 148 & 1.36 & $5.05^{* * *}$ & $19.0 \%$ & $19.8 \%$ \\
\hline Maternal age & 1 & 0.10 & $0.38 \mathrm{NS}$ & $0.0 \%$ & $0.0 \%$ \\
\hline Age $\times \operatorname{dam}($ sire $)$ & 192 & 0.29 & $1.07 \mathrm{NS}$ & $0.0 \%$ & $0.0 \%$ \\
\hline Age $\times \operatorname{sex}$ & 1 & 0.06 & $0.23 \mathrm{NS}$ & - & - \\
\hline Error & 2790 & 0.27 & & $67.0 \%$ & $64.1 \%$ \\
\hline \multicolumn{6}{|l|}{ Egg length } \\
\hline Sire & 50 & 0.254 & $3.25^{* * *}$ & - & $29.1 \%$ \\
\hline $\operatorname{Dam}($ sire $)$ & 143 & 0.078 & $1.98^{* * *}$ & - & $12.6 \%$ \\
\hline Maternal age & 1 & 0.029 & $0.74 \mathrm{NS}$ & - & $0.0 \%$ \\
\hline Age $\times \operatorname{dam}($ sire $)$ & 170 & 0.044 & $1.11 \mathrm{NS}$ & - & $0.0 \%$ \\
\hline Error & 906 & 0.039 & & - & $68.9 \%$ \\
\hline \multicolumn{6}{|l|}{ Egg width } \\
\hline Sire & 50 & 0.092 & $2.67^{* * *}$ & - & $15.0 \%$ \\
\hline Dam(sire) & 143 & 0.035 & $2.43^{* * *}$ & - & $17.9 \%$ \\
\hline Maternal age & 1 & 0.002 & $0.16 \mathrm{NS}$ & - & $0.0 \%$ \\
\hline Age $\times$ dam(sire $)$ & 170 & 0.014 & $0.97 \mathrm{NS}$ & - & $0.0 \%$ \\
\hline Error & 906 & 0.014 & & - & $67.2 \%$ \\
\hline
\end{tabular}

Type III sums of squares were calculated using SAS GLM (SAS Institute, 1985), with sex and age treated as fixed effects, and sire and dam as random effects. The proportion of the variance explained was estimated using the restricted maximum likelihood method of SAS VARCOMP, treating age as a random effect and sorting by sex. ${ }^{* * *} P<0.001 ; \mathrm{NS}$, not significant. 
action were highly significant. Although maternal age explained less than 2 per cent of the total phenotypic variance in development time, the age $\times$ dam interaction explained as much as 12.1 per cent of the variance (Table 4). This interaction is likely to be the result of an egg-order effect on development time coupled with variation in fecundity schedule: later-laid eggs develop more slowly, and because some females laid few eggs in age-class 1 , while others laid many eggs in age-class 1 , this effect is detected as an age $\times$ dam interaction rather than as a maternal age effect.

\section{Phenotypic and genetic correlations between life history characters}

Because rearing dish explained negligible amounts of the observed phenotypic variance (see above), this effect was ignored when calculating genetic and environmental correlations. The following results represent the correlations between pairs of offspring characters, and not the correlations between parental and offspring characters.

The phenotypic correlations between both measures of egg size (egg length and egg width) were positive, and both were positively correlated with adult body size (Table 5). Development time, on the other hand, was negatively phenotypically correlated to both egg size and body size.

The additive genetic correlations, however, were very different from the phenotypic correlations (Table 5 ). While egg length and egg width were still positively correlated with each other, neither was significantly correlated with body size. In addition, whereas the phenotypic correlations between development time and each measure of egg size and body size were negative, the additive genetic correlations were all positive.

Maternal correlations between pairs of characters are not presented because the maternal variances used in calculating these correlations were near zero (see above). Thus, small sampling errors produced dramatic fluctuations in the maternal correlations. Estimated correlations ranged from greater than 1 to less than -1 , with no interpretable patterns.

\section{Discussion}

Contrary to my expectation that variation in egg size would be largely maternally induced, resulting in multigeneration transmission of a maternal body size effect on offspring life history, the data presented here indicate that multigeneration maternal transmission of body size or egg size does not occur in Callosobruchus maculatus. Instead, both body size and egg size (egg length and width) were highly heritable characters (estimated $h^{2}>0.55$ for each character; Table 3 ), and the proportion of the variance explained by maternal effects was near zero for each (Tables 1 and 2). These results indicate that variation in egg size and offspring body size are not maternally transmitted across generations, but instead that most of the variation in these characters is additive genetic variation.

Although maternal effects were undetectable for either adult body size or offspring egg size, they do appear to affect early larval life history. Female body size is positively correlated (phenotypically) with the size of her eggs (Fig. 1), and thus with her resource

Table 5 Phenotypic correlations $\left(r_{\mathrm{P}}\right)$ and additive genetic correlations $\left(r_{\mathrm{A}}\right)$ between life history characters of Callosobruchus maculatus

\begin{tabular}{lrr}
\hline Correlated traits & \multicolumn{1}{c}{$r_{\mathrm{p}}$} & \multicolumn{1}{c}{$r_{\mathrm{A}}$} \\
\hline Females & & \\
$\quad$ Egg length vs. egg width & $0.372^{* * *}$ & $0.498^{* * *}$ \\
Body weight vs. egg length & $0.243^{* * *}$ & $-0.154 \mathrm{NS}$ \\
Body weight vs. egg width & $0.186^{* * *}$ & $0.005 \mathrm{NS}$ \\
Development time vs. egg length & $-0.345^{* * *}$ & $0.266 \mathrm{NS}$ \\
Development time vs. egg width & $-0.540^{* * *}$ & $0.502^{* * *}$ \\
Body weight vs. development time & $-0.084 \mathrm{NS}$ & $0.438^{* * *}$ \\
Males & & \\
Body weight vs. development time & $-0.150^{*}$ & $0.999^{* * *}$ \\
\hline
\end{tabular}

${ }^{*} P<0.05,{ }^{* *} P<0.01,{ }^{* * *} P<0.001 ; \mathrm{NS}=$ not significant.

Variances and covariances used to calculate correlations were estimated with the restricted maximum likelihood method of SAS VARCOMP (SAS Institute, 1985), where $\operatorname{cov}(X, Y)=[\operatorname{var}(X+Y)-\operatorname{var}(X)-\operatorname{var}(Y)] / 2$ (Sokal \& Rohlf, 1981).

Significance tests are approximations based on the magnitude of the correlation and the sample size, using the method of Maindonald (1984). 
contribution to hatchlings. This correlation appears to be a maternal size effect on hatchling resources (i.e. egg size): the phenotypic correlation between female size and egg size was substantially larger than the estimated genetic correlation (Table 5), indicating that this is largely a nongenetic correlation. Subsequently, this initial disadvantage to larvae results in extended larval development time, but not in an effect on final adult size. Other studies have also found evidence for large maternal effects on newly hatched young, and early growth of these young, which did not translate into maternal effects on final adult size (Ankney, 1980; Price \& Grant, 1985; Reid \& Boersma, 1990).

I speculate that $C$. maculatus larvae are compensating for small egg size by developing longer and attaining a genetically targeted body size. Although a maternal effect was detected on embryonic resources (estimated as egg size; Fig. 1) and on offspring development time (Table 1), final offspring characteristics (body weight of sons and daughters, and the size of daughters' eggs; Tables 1 and 2) were not influenced by maternal effects. Similarly, previous results on $C$. maculatus have indicated that beetles developing from small eggs developed longer, and eventually attained the same size as their full-sibs developing from larger eggs (Fox, 1993; Fox \& Dingle, 1994). Thus, while maternally induced, nongenetic variation in egg size (within families) may have dramatic influences on early C. maculatus larval development; these larvae apparently develop towards a genetically determined adult size, and evidence of maternal effects disappears by the time offspring reach the adult stage.

This experiment has also indicated a within-family source of maternal variance due to maternal age, consistent with previous work on $C$. maculatus: older mothers lay smaller eggs, and offspring from these eggs develop more slowly and have lower survivorship than offspring from earlier laid eggs (Wasserman \& Asami, 1985; Fox, 1993; Fox \& Dingle, 1994). In this experiment, I detected a maternal age effect on offspring development time within the first $24 \mathrm{~h}$ (detected here as an age $\times$ dam interaction; Table 4 ). No effects of maternal age on offspring body size, or on a daughter's egg size, were detected here (Table 4). This is consistent with my previous work, in which body size was independent of maternal age (Fox, 1993) or at best weakly affected by maternal age (Fox \& Dingle, 1994).

Another interesting result of this experiment concerns the difference in sign of the genetic and phenotypic correlations between development time and all other characters (Table 5). The negative phenotypic correlations indicate that individuals developing more quickly are producing larger eggs and achieving a larger body size. This is possibly a result of each trait being affected by the quality of resources within their seeds (e.g. high quality seeds produce fast developing, large larvae that produce large eggs). The positive genetic correlations, on the other hand, indicate that some genes which delay development tend to increase egg size, while other genes extending development increase body size (or vice versa, genes that increase body size result in extended development). That the genes influencing egg size are different from the genes influencing body size is suggested by the near-zero genetic correlations between egg size and body size (Table 5 ).

In summary, maternal effects on offspring development time are detectable both within families (due to maternal age; Table 4) and among families (Table 1). However, maternal egg size and body size effects have no detectable effect on offspring body size (at adult) or the size of their eggs, indicating that body size and egg size variation are not maternally (nongenetically) transmitted across multiple generations.

\section{Acknowledgements}

I thank H. Dingle and J. A. Rosenheim for laboratory space and equipment. D. L. Hickman helped measure beetles. F. J. Messina provided beetle populations and many helpful discussions concerning beetle biology. I also thank S. P. Carroll, R. L. Caldwell, H. Dingle, D. D. Heath, M. J. Kearsey, L. A. McLennan, T. A. Mousseau, T. Prout, R. G. Shaw and one anonymous reviewer for helpful discussions and/or comments on this manuscript.

\section{References}

ANKNEY, C. D. 1980. Egg weight, survival, and growth of lesser snow goose goslings. J. Wildl. Management., 44, 174-182.

ANTONOVICS, J. AND SCHMITT, J. 1986. Paternal and maternal effects on propagule size in Anthoxanthum odoratum. Oecologia, 69, 277-282.

BECKER, W. A. 1992. Manual of Quantitative Genetics. Academic Enterprises, Pullman, WA.

BERGER, A. 1989. Egg weight, batch size and fecundity of the spotted stalk borer, Chilo partellus in relation to weight of females and time of oviposition. Entomologia exp. appl., 50, 199-207.

BERRIGAN, D. 1991. The allometry of egg size and number in insects. Oikos, 60, 313-321.

BIERE, A. 1991. Parental effects in Lychnis flos-cuculi. I. Seed size, germination, and seedling performance in a controlled environment. J. Evol. Biol., 3, 447-465.

CARLBERG, U. 1991. Egg-size variation in Extatosoma tiaratum (MacLeay) and its effect on survival and fitness of newly hatched nymphs (Insecta; Phasmida). Biol. Z $\mathrm{bl}$., 110, 163-173. 
CHIU, Y.-J. AND MESSINA, F. J. 1994. Effect of experience on host preference in Callosobruchus maculatus (Coleoptera: Bruchidae): variability among populations. J. Insect Behav., (in press).

DOUGLAS, G. B., GORDON, I. L., CHU, A. C. P. AND ROBERTSON, A. G. 1993. Effect of genotype and seed size on early vegetative growth of sheep's burnet. N. Z. J. Agric. Res., 36, 109-116.

FALCONER, D. S. 1965. Maternal effects and selection response. Genetics Today, 3, 763-774.

FALCONER, D. S. 1989. Introduction to Quantitative Genetics, 3rd edn. Longman, New York.

FLEMING, I. A. AND GRoSS, M. R. 1990. Latitudinal clines: a trade-off between egg number and size in pacific salmon. Ecology, 71, 1-11.

Fox, C. W. 1993. The influence of maternal age and mating frequency on egg size and offspring performance in Callosobruchus maculatus (Coleoptera: Bruchidae). Oecologia, 96, 139-146.

Fox, c. w. 1994. The influence of egg size on offspring performance in the seed beetle, Callosobruchus maculatus. Oikos (in press).

FOX, C. W. AND DINGLE, H. 1994. Dietary mediation of maternal age effects on offspring performance in a seed beetle (Coleoptera: Bruchidae). Funct. Ecol. (in press).

HARVEY, G. T. 1983. A geographic cline in egg weights in Choristoneura fumifera (Lepidoptera: Tortricidae) and its significance in population dynamics. Can. Ent., 115, 1103-1108.

HONEK, A. 1987. Regulation of body size in a heteropteran bug, Pyrrhocoris apterus. Entomologia exp. appl., 44, 257-262.

HUYGHE, C. 1993. Growth of white lupin seedlings during the rosette stage as affected by seed size. Agronomie, 13, 145-153.

KAPLAN, R. H. 1980a. The implications of ovum size variability for offspring fitness and clutch size within several populations of salamanders (Ambystoma). Evolution, 34, 51-64.

KAPLAN, R. H. 1980 b. Ontogenetic energetics in Ambystoma. Physiol. Zool., 53, 43-56.

KAPLAN, R. H. 1990. Developmental plasticity and maternal effects in amphibian life histories. In Dudley, E. C. (ed.) The Unity of Evolutionary Biology, Vol. II, pp. 794-799. Dioscordies Press, Portland, OR.

KIRKPATRICK, M. AND LANDE, R. 1989. The evolution of maternal characters. Evolution, 43, 485-503.

LANDE, R. AND KIRKPATRICK, M. 1990. Selection response in traits with maternal inheritance. Genet. Res., 55, 189-197.

LACEY, E. P. 1990. Parental effects on life-history traits in plants. In Dudley, E. C. (ed.) The Unity of Evolutionary Biology, Vol. II, pp. 735-744. Dioscordies Press, Portland, OR.

LARSSON, K. AND FORSLUND, P. 1992. Genetic and social inheritance of body and egg size in the barnacle goose (Branta leucopsis). Evolution, 46, 235-244.

maindonald, J. H. 1984. Statistical Computation. Wiley, New York.
MARTEINSDOTTIR G. AND ABELE, K. W. 1992. Influence of egg size on embryos and larvae of Fundulus heteroclitus (L.). J. Fish Biol., 41, 883-896.

MAZER, S. J. 1987. The quantitative genetics of life history and fitness components in Raphanus raphanistrum L. (Brassicaceae): ecological and evolutionary consequences of seed-weight variation. Am. Nat., 130, 891-914.

McGiNLEY, M. A., TEMME, D. H. AND GEBER, M. A. 1987. Parental investment in offspring in variable environments: theoretical and empirical considerations. Am. Nat., 130, $370-398$.

MESSINA, F. J. 1991. Life-history variation in a seed beetle: adult egg-laying vs. larval competitive ability. Oecologia, $\mathbf{8 5}, 447-455$.

MESSINA, F. J. AND RENWICK, J. A. A. 1985a. Ability of ovipositing seed beetles to discriminate between seeds with differing egg loads. Ecol. Entomol., 10, 225-230.

MESSINA, F. J. AND RENWICK, J. A. A. 1985b. Mechanism of egg recognition by the cowpea weevil Callosobruchus maculatus. Entomologia exp. appl., 37, 241-245.

MITCHELL, R. 1975. The evolution of oviposition tactics in the bean weevil, Callosobruchus maculatus (F.). Ecology, 56, 696-702.

MoUSSEAU, T. A. AND DiNGLE, H. 1991. Maternal effects in insect life histories. Ann. Rev. Ent., 36, 511-534.

PLATENKAMP, G. A. J. AND SHAW, R. G. 1993. Environmental and genetic maternal effects on seed characters in Nemophila menziesii. Evolution, 47, 540-555.

PRICE, T. D. AND GRANT, P. R. 1985. The evolution of ontogeny in Darwin's finches: a quantitative genetic approach. Am. Nat., 125, 169-188.

REID, w. V. AND BOERSMA, P. D. 1990. Parental quality and selection on egg size in the magellanic penguin. Evolution, 44, 1780-1786.

REZNICK, D. N. 1990. Maternal effects in fish life histories. In: Dudley, E. C. (ed.) The Unity of Evolutionary Biology, Vol. II, pp. 780-793. Dioscordies Press, Portland, OR.

RICHARDS, L. J. AND MYERS, J. H. 1980. Maternal influences on size and emergence time of the cinnabar moth. Can. J. Zool., 58, 1452-1457.

RISKA, B. 1990. Introduction to the symposium. In: Dudley, E. C. (ed.) The Unity of Evolutionary Biology, Vol. II, pp. 719-724. Dioscordies Press, Portland, OR.

RISKA, B., RUTLEDGE, J. J. AND ATCHLEY, W. R. 1985. Covariance between direct and maternal genetic effects in mice, with a model of persistent environmental influences. Genet. Res., 45, 287-295.

ROACH, D. A. AND WULFF, R. 1987. Maternal effects in plants: evidence and ecological and evolutionary significance. Ann. Rev. Ecol. Syst., 18, 209-235.

ROSSITER, M. C. 1991. Maternal effects generate variation in life history: consequences of egg weight plasticity in the gypsy moth. Funct. Ecol., 5, 386-393.

SAS INSTITUTE 1985. SAS User's Guide: Statistics, Version 5 Edition. SAS Institute, Cary, NC.

SCHWAEGERLE, K. E. AND LEVIN, D. A. 1990. Quantitative genetics of seed size variation in Phlox. Evol. Ecol., 4, 143-148. 
SIBLY, R. AND MONK, K. 1987. A theory of grasshopper life cycles. Oikos, 48, 186-194.

SIMMONS, L. w. 1988. The contribution of multiple mating and spermatophore consumption to the lifetime reproductive success of female field crickets (Gryllus bimaculatus). Ecol. Entomol., 13, 57-69.

SINERVO, B. 1990. Experimental and comparative analyses of egg size in lizards: constraints on the adaptive evolution of maternal investment per offspring. In: Dudley, E. C. (ed.) The Unity of Evolutionary Biology, Vol II. pp. 725-734. Dioscordies Press, Portland, OR.

SOKAL, R. R. AND ROHLF, F. J. 1981. Biometry, 2nd edn. W. H. Freeman, New York.

SOLBRECK, C., OLSSON, R., ANDERSON, D. B. AND FORARE, J. 1989. Size, life history and response to food shortage in two geographical strains of the seed bug Lygaeus equestris. Oikos, 55, 387-396.

SOTA, T. AND MOGI, M. 1992. Interspecific variation in desiccation survival time of Aedes (Stegomyia) mosquito eggs is correlated with habitat and egg size. Oecologia, 90, 353-358.

STANTON, M. L. 1984. Seed variation in wild radish: effect of seed size on components of seedling and adult fitness. Ecology, 65, 1105-1112.

STEINWASCHER, K. 1984. Egg size variation in Aedes aegypti: relationship to body size and other variables. Am. Midl. Natur., 112, 76-84.

TAUBER, C. A., TAUBER, M. J. AND TAUBER, M. J. 1991. Egg size and taxon: their influence on survival and development of chrysopid hatchlings after food and water deprivation. Can. J. Zool., 69, 2644-2650.

THOMPSON, K., BAND, s. R. AND hodgson, J. G. 1993. Seed size and shape predict persistence in soil. Funct. Ecol., 7, 236-241.

TOQUENAGA, y. 1993. Contests and scramble competitions in Callosobruchus maculatus (Coleoptera: Bruchidae). 2. Larval competition and interference mechanisms. Res. Pop. Biol., 35, 57-68.

WALLIN, H., CHIVERTON, P. A., EKBOM, B. S. AND BORG, A. 1992. Diet, fecundity and egg size in some polyphagous predatory carabid beetles. Entomologia exp. appl., 65, 129-140.

WASSERMAN, S. S. AND ASAMI, T. 1985. The effect of maternal age upon fitness of progeny in the southern cowpea weevil, Callosobruchus maculatus. Oikos, 45, 191-196.

WILSON, K. 1988. Egg laying decisions by the bean weevil Callosobruchus maculatus. Ecol. Entomol., 13, 107-118.

WULFF, R. D. 1986 a. Seed size variation in Desmodium paniculatum. II. Effects on seedling growth and physiological performance. J. Ecol., 74, 99-114.

WULFF, R. D. 1986 b. Seed size variation in Desmodium paniculatum. III. Effects on reproductive yield and competitive ability. J. Ecol., 74, 115-121.

YUMA, M. 1984. Egg size and variability of the firefly, Lucioloa cruciata (Coleoptera, Lampyridae). Kontyu, 52, 615-629.

ZHANG, J. AND MAUN, M. A. 1993. Components of seed mass and their relationships to seedling size in Calamovilfa longifolia. Can. J. Bot., 71, 557-567. 